\title{
ELECTRONIC VISUALIZATION OF UNDERGROUND TOURIST ROUTES ON THE EXAMPLE OF THE ROUTE IN SANDOMIERZ
}

\author{
AGH University of Science and Technology, Kraków, Poland \\ gawalkie@agh.edu.pl
}

Keywords: map of underground tourist attractions, inventory of underground facilities

\begin{abstract}
For many years in Poland, anthropogenic objects constructed underground have been very popular with tourists. In the past they fulfilled various functions (historic mines, underground merchant warehouses, military objects, special objects, caverns and grottoes). Many of them were secured and rebuilt in such a way that a new form was created. They make interesting tourist offers and still more objects can be made available to tourists. An example of strongly modified underground anthropogenic objects of very complex geometry and extremely interesting architectural form is the Underground Tourist Route (Polish: Podziemna Trasa Turystyczna - PTT) in Sandomierz. Owing to much effort and financial means, in 1960s many interesting cellars and merchant warehouses were saved from destruction - and - with the application of mining techniques, they were joint into attractive spatial forms. So far, few publications give the full characteristic and parametric data of this object. Today's possibilities of available measurement and information technologies allow comprehensive inventory of complicated engineering constructions, as well as the $3 \mathrm{D}$ visualization, regarding even tiniest elements of small architecture (doors, lattice, lamps, etc.). The article presents the results of the visualization and parameterization based on the data from integrated surveying (levelling, transects, total stations, laser scanning and other direct measurements).
\end{abstract}

\section{ELEKTRONICZNA WIZUALIZACJA PODZIEMNYCH TRAS TURYSTYCZNYCH NA PRZYKLADZIE TRASY W SANDOMIERZU}

Słowa kluczowe: mapa podziemnych atrakcji turystycznych, inwentaryzacja infrastruktury podziemnej

\begin{abstract}
Abstrakt
W Polsce dużą popularnością turystyczną od lat cieszą się obiekty antropogeniczne wzniesione pod powierzchnią ziemi, pełniące różnorodne funkcje użytkowe w przeszłości (zabytkowe kopalnie, podziemne składy kupieckie, obiekty militarne, obiekty specjalne, jaskinie i groty). Wiele z nich zostało w stopniu istotnym zabezpieczone i przebudowane w taki sposób, by nadać im nową formę. Udostępnione, dziś stanowią ciekawe oferty turystyczne, a ich liczba stanowi dziś zbiór otwarty. Przykładem mocno przetworzonego podziemnego obiektu antropogenicznego o bardzo zróżnicowanej geometrii i niezwykle ciekawej formie architektonicznej jest Podziemna Trasa Turystyczna w Sandomierzu. Dzięki zaangażowaniu wielu środków udało się w latach 60. XX w. ocalić od zniszczenia wiele interesujących piwnic i składów kupieckich i połączyć je z zastosowaniem technik górniczych w atrakcyjne formy przestrzenne. Dotychczas powstało niewiele opracowań, które ukazałyby w pełni ich charakterystykę oraz sparametryzowały obiekt. Możliwości dostępnych dzisiaj technik pomiarowych oraz informatycznych pozwalają na kompleksową inwentaryzację skomplikowanych budowli inżynierskich, a także wizualizację przestrzenną z uwzględnieniem nawet najdrobniejszych elementów małej architektury (drzwi, kraty, lampy itp.). W artykule zaprezentowano wyniki wizualizacji i parametryzacji na podstawie danych zintegrowanych pomiarów geodezyjnych (niwelacji, poligonizacji, tachimetrii elektronicznej, skaningu laserowego i innych pomiarów bezpośrednich).
\end{abstract}




\section{INTRODUCTION}

Many places in Poland played an important role in history. Many of them were signs of power in military, economic and social aspect, owing to the localization, topography and the interest of subsequent rulers from the early Middle Ages. Other were formed by nature unique caves and grottoes, although often hard to access, also today make very attractive points on the tourist map of Poland. Local authorities and local history amateurs have been aware of the potential of many such places, and their activities also have been contributing to the revitalization of forgotten objects and bringing them back to life. Particularly interesting for tourists are objects located underground. Often mysterious and hidden under the surface, they hide rich history of social life, economic activities and defence potential. Today they make a peculiar magnet and contribute to the pop- ularization of the region, also among foreign tourists. Moreover, they stimulate economic development of the region, providing money to local self-governments.

For many years the regulations have been requiring that the owners or custodians have up-to-date technical (engineering) documentation, which is basic for all the renovation works (mending, converting). Usually, such documentation concentrates around classical 2D documents or (rarer) pseudo3D (the example can be the Underground Tourist Route in Opatów). The availability and functionality of CAD programs allow making more advanced documentation in the form of $3 \mathrm{D}$ models (e.g., underground mines, including historic mines Ochirsukh 2019). So popular nowadays 3D visualizations give possibility of better knowledge of the geometry of the underground object and getting more readable form of presentation in advertisements, educational materials, and historic materials, as well as presentations

\section{JASKINIE i GROTY / CAVES AND GROTTOES:}

1. Mroźna, 2. Mylna, 3. Obłazkowa, 4. Raptawicka, 5. Smocza Jama w Wąwozie Kraków, 6. Dziura w Dolinie ku Dziurze, 7. Malinowska, 8. Zimna Dziura w Szczeblu, 9. Smocza Jama na Wawelu, 10. Wierzchowska Górna, 11. Łokietka, 12. Ciemna, 13. Nietoperzowa, 14. Ostrężnica, 15. na Biśniku, 16. Głęboka, 17. Raj, 18. Piekło, 19. Zbójecka, 20. Niedźwiedzia, 21. Radochowska, 22. G.Mechowskie, 23. Szczelina w Geoparku Kadzielnia w Kielcach

\section{KOPALNIE i SZTOLNIE / MINES AND TUNNELS:}

1. Kopalnia Soli w Wieliczce: Muzeum Żup Krakowskich, Trasa Turystyczna, Uzdrowisko, 2. Kopalnia Soli w Bochni: Trasa Turystyczna, Uzdrowisko, 3. Kłodawska Podziemna Trasa Turystyczna w Kopalni Soli "Kłodawa” S.A., 4. Chełmskie Podziemia Kredowe, 5. Neolityczna Kopalnia Krzemienia w Krzemionkach Opatowskich, 6. Kopalnia Złota Aurelia w Złotoryi, 7. Kopalnia Złota Złoty Stok, 8. Muzeum Górnictwa Rud Żelaza w Częstochowie, 9. Zabytkowa Kopalnia Srebra w Tarnowskich Górach, 10. Stara Kopalnia Uranu w Kletnie, 11. Sztolnie w Kowarach: Kopalnia "Podgórze" i Kopalnia "Liczyrzepa", 12. Kopalnia Węgla Kamiennego w Nowej Rudzie, 13. Skansen Górniczy "Królowa Luiza” w Zabrzu, 14. Sztolnia "Czarnego Pstrąga” w Tarnowskich Górach, 15. Zabytkowa Kopalnia Węgla Kamiennego "Guido" w Zabrzu, 16. Sztolnia Ćwiczebna Muzeum Miejskiego "Sztygarka” w Dąbrowie Górniczej, 17. Sztolnia Ćwiczebna w Wodzisławiu Śląskim, 18. Groty Nagórzyckie w Tomaszowie Mazowieckim

\section{OBIEKTY POMILITARNE: / POST-MILITARY FACILITIES:}

1. Schron kolejowy w Stępinie, 2. Schron kolejowy w Strzyżowie, 3. Bunkier kolejowy w Konewce, 4. Twierdza Kłodzko Chodniki Minerskie "Labirynt", 5. Międzyrzecki Rejon Umocniony: Pętla Boryszyńska, trasa w Kaławie, 6. Podziemia Twierdzy Modlin, 7. Podziemny Szczecin, 8. Poniemieckie Schrony Przeciwlotnicze w Krakowie, 9. Program Riese (Olbrzym): Kompleks Włodarz, Muzeum Sztolni Walimskich, Podziemne Miasto Osówka, Zamek Książ, 10. Twierdza Kostrzyn, 11. Twierdza Osowiec, 12. Twierdza Toruń - Fort IV, 13. Twierdza w Srebrnej Górze, 14. Twierdza Warszawa, 15. Twierdza Zamość - trasa turystyczna w Bastionie VII, 16. Wał Pomorski Grupa Warowna - Góra Śmiadowska, 17. Podziemia Będzińskie, 18. Twierdza Grudziądz

PIWNICE I SKLADY / CELLARS AND WAREHOUSES:

1. Rzeszowskie Piwnice, 2. Lochy Sandomierskie, 3. Podziemia Opatowskie, 4. Lubelska Trasa Podziemna, 5. Podziemna Trasa Turystyczna im. 1000-lecia Państwa Polskiego w Kłodzku

\section{INNE OBIEKTY PODZIEMNE / OTHER UNDERGROUND FACILITIES:}

1. Elektrownia Wodna Solina, 2. Elektrownia Wodna Niedzica, 3. Groby Królewskie na Wawelu, 4. Krypty w Kościele oo. Paulinów na Skałce w Krakowie, 5. Krypty w Kościele oo. Reformatów w Krakowie, 6. Grota Puławska, 7. Krypty w Kościele oo. Filipinów w Gostyniu, 8. Krypty kościelne na Świętym Krzyżu, 9. Krypty koscielne Bazyliki Archikatedralnej Świętych Apostołów Piotra i Pawła w Poznaniu

\section{PLANOWANE OBIEKTY TURYSTYCZNE / PLANNED TOURIST FACILITIES:}

1. Kamieniołom w Bochotnicy, 2. Sztolnie w Senderkach, 3. Sztolnie w Jarmucie, 4. Wyrobiska pokopalniane w Olkuszu,

5. Sztolnie pod Wielisławką w Sędziszowem, 6. Elizeum w Warszawie, 7. Twierdza Łomża, 8. Piwnice i lochy w Szczebrzeszynie, 9. Piwnice i lochy w Hrubieszowie, 10. Muzeum podziemne w Olkuszu, 11. Piwnice w Jarosławiu 
among disabled people, for which many of these objects are simply unavailable. This paper presents the results of contemporary inventory "Sandomierz Dungeons" (Polish: Sandomierskie Lochy), with the application of modern surveying methods based on mirrorless technologies, including automation and nowadays widespread laser scanning.

The article presents morphometric characteristic and visualisation of the Underground Tourist Route in Sandomierz, based on integrated surveying data.

\section{DIVISION OF UNDERGROUND TOURIST ROUTES}

The analysed in this article tourist object, belongs to underground constructions. According to (Glinicki 1994), underground constructions are engineering constructions below the terrain surface. Basic burden of these constructions is weight and pressure of the surrounding ground (especially the overlying ground - external load). In the case of their shallow situation, addi-

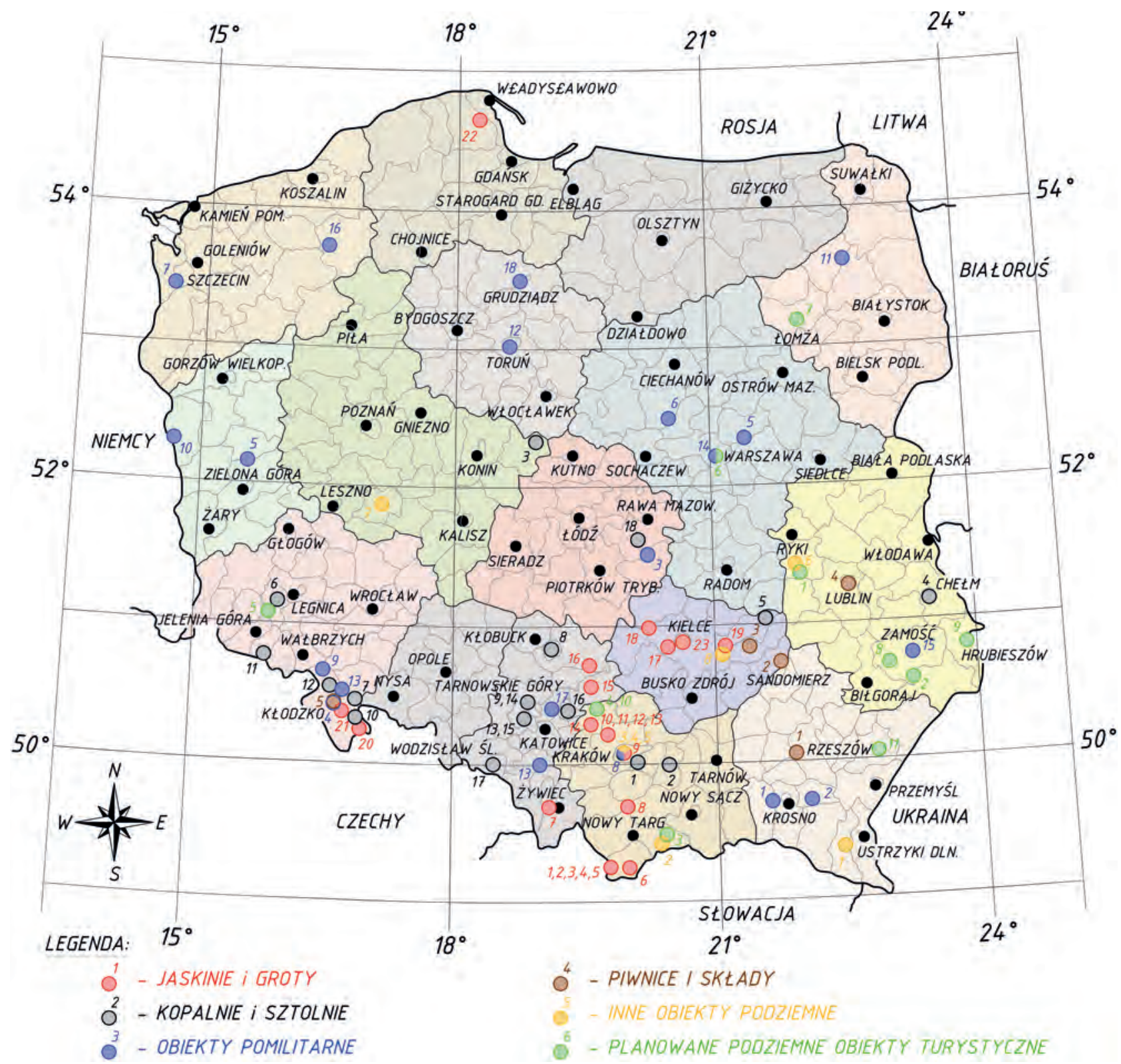

Fig. 1. Location of underground tourist routes in Poland (including planned ones)

Rys. 1. Lokalizacja podziemnych tras turystycznych w Polsce (w tym planowanych) 
tion factor influencing the underground constructions is the burden originating from buildings (e.g., apartment houses) localized on the surface and situated directly over the underground excavation. Thus, it is necessary to provide the definition of underground excavation, because the analysed route in Sandomierz is an object of this type. The underground excavation is an empty void in the ground centre, made on purpose (regardless the function) made after removing the ground. It is also assumed that geometric axes of excavations can run horizontally or aslope.

Regarding the origin of underground buildings and their initial functions, tourist underground routes were divided into 5 groups, such as: caves (natural objects), mines and shafts, military objects, cellars and stores, as well as other anthropogenic underground objects.

Based on the author's query, scientific materials, guidebooks and travels, a map of the localization of functioning in a public space underground tourist routes of natural and anthropogenic origin was made, which is presented in figure 1.

\section{ORIGIN OF THE CONSTRUCTION AND THE WAYS OF BUILDING UP THE SANDOMIERZ DUNGEONS (POLISH: LOCHY SANDOMIERSKIE)}

The tourist attractiveness of cities and towns in Poland is determined by their history and the presence of architectural objects, which, because of their unique character and appearance make Polish and foreign tourists amazed. Such a jewel in Poland is Sandomierz, belonging to the most precious historic urbanistic-andscape complexes (Krawczyk 2010). Sandomierz is often called "Little Rome" (Gawałkiewicz and Szafarczyk 2017). Like Rome, the capital of Italy, Sandomierz is situated on seven hills, although, in case of Sandomierz, these are loess hills. Since early Middle Ages, Sandomierz was an important commercial centre the routes of which led to Przemyśl, Halych, Volodymyr-Volynskyi and further to Kiev.

Devastating Mongol invasions into the Sandomierz Region in 1241 and 1259-1260 made Duke Leszek the Black transfer the "new" city into higher, more difficult to access part of the hill, limited by a scarp from the side of the Vistula River. The contribution by Leszek the Black to the development of the city was appreci- ated by the authors of the Underground Tourist Route by naming one of geometrically unique galleries after him (fig. 5). While building a new city, perspectives and directions in its development, dangers connected with military invasions were taken into account. These factors determined urban development of the city and the way of its fortification. Such an approach brought the result already in 1287, during subsequent Mongol invasion when the invaders failed to conquer the city. The legend says that the successful defence was also due to the network of underground tunnels located under the city, used as traps. But the network of cellars located under the existing superstructure, mostly wooden buildings and the adjacent streets and squares, was mainly the place of merchants' stores serving the restored international commerce with the participation of Poles. The development of commerce caused the need of collecting large quantities of goods in a limited urban space. Thus it was a period of increased activities carried out by merchants under the surface of the ground (the geology of the loess hills of the thickness up to 30 $\mathrm{m})$, connected with digging the network of multi-level stores, chambers and cellars in the rock mass under the merchants' houses and their neighbourhood.

With time, the need for this type of store objects, resulting from the intensification of trade, lead to immense expansion of underground voids. The lack of proper security measures of walls and vaults of underground objects, change of water balance, erosion of the loess rock mass, change of the burden of the ground due to surface objects, in the second half of $19^{\text {th }}$ century led to many catastrophes due to sinkholes. Many of the caverns, of small historic and utilitarian value, were filled with sand for the safety of buildings and people. Some constructions, in a slightly changed form and shape was included into the underground tourist route, as illustrated in figure 5.

Building other urban centres in the neighbourhood, the loss of trade privileges caused that in $18^{\text {th }}$ century underground labyrinths of stores and warehouses became forgotten. A series of events that started 1857 made the authorities face a big problem. It was connected with notorious construction catastrophe taking place near the Zawichojska Gate. As a result of the activation of old practically unprotected underground voids, more than 100-metre-long section of city walls with the adjacent buildings collapsed. Since that moment, in the city records, notes about other such catastrophes could 
be found. The catastrophes were caused by the loss of stability of underground galleries and collapses on the surface. Intensification of construction catastrophes in 1960 s prompted repairing measures connected with voids and objects were listed into the register on the surface. Because of the history of the city and its material resources, to protect the mentioned above objects, they were listed into the register of historic monuments as urbanistic-architectonic and landscape complex (reg. no.: A.719 of $09^{\text {th }}$ January $1947,10^{\text {th }}$ January 1966 r., $25^{\text {th }}$ February 1977 and $10^{\text {th }}$ April 1984). This required the activities aimed at the fundaments of these objects and the underground. A team of scientists led by Professor Zbigniew Strzelecki of the AGH University of Science and Technology, based on the results of geotechnical studies made plans to secure urban infrastructure. The plans were implemented by the Bytom Mining Enterprise - in Polish -Bytomskie Przedsiębiorstwo Robót Górniczych (Tajduś et al. 2008; Mikoś et al. 2013).

The present shape of the underground route was formed due to the analyses of the usefulness of subsequent fragments of the underground (the assessment of the technical state and stability) for the adaptation for tourist purposes (fig. 5). The effect of the implemented concept is nowadays the Underground Tourist Route, also called the Sandomierz Dungeons (Sandomierskie Lochy). This is an urbanist-architectonic complex, making a functional special unit, singled out from the space of the Old Town. It was the initiative of the members of the local Unit of the Polish Tourist and Sightseeing Society (Polskie Towarzystwo Turystyczno-Krajoznawcze, PTTK), which financed nearly $50 \%$ costs of constructing the route. Huge contribution of work and finances to make something new, based on the complex of individual merchant's cellars under the old city centre, and the adaptation of the selected for tourists, was appreciated by the city authorities of those times. Based of the solemn act of $10^{\text {th }}$ December 1977, the City Mayor's Office, represented by the deputy head of the voivodeship Władysław Dziadkowiec transferred the rights to lease the object and carry out tourism, to the Sandomierz Unit of PTTK (Gawałkiewicz 2018).

Due to the specific character of the object, making the underground voids to tourists required many technical and construction solutions implemented in mining. Thus, it was necessary to apply the brick or concrete frame of the shape adjusted to the geometry of the fragments of existing and relatively well preserved part, a)

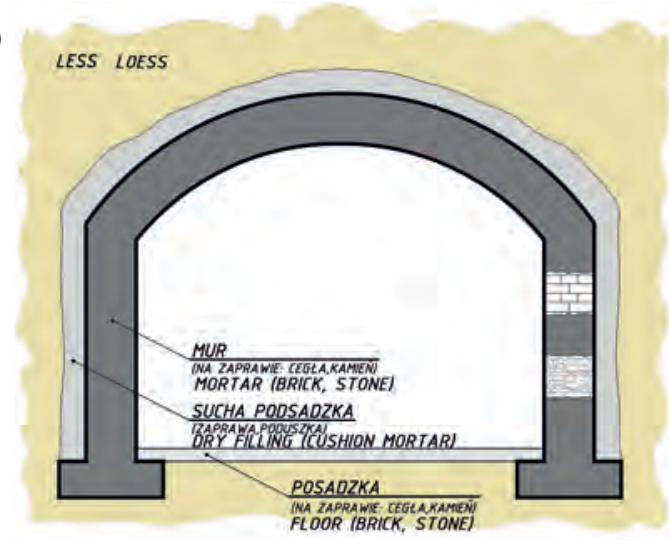

b)

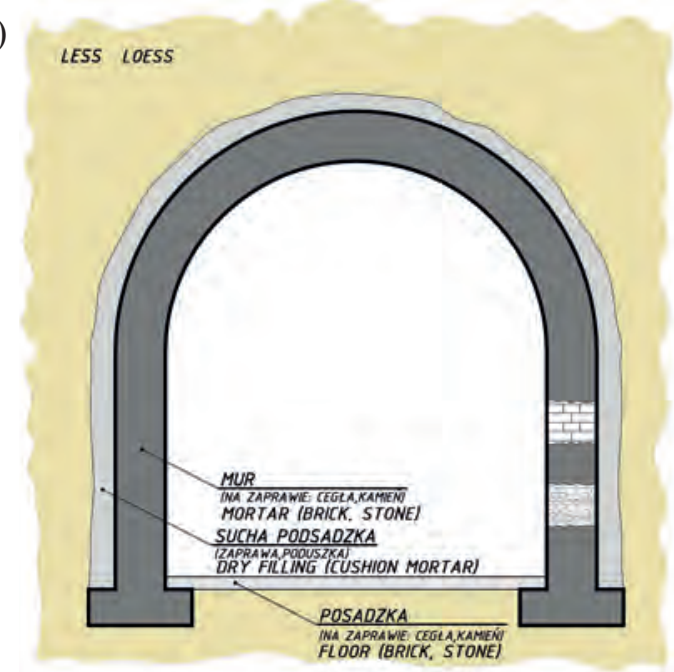

c)

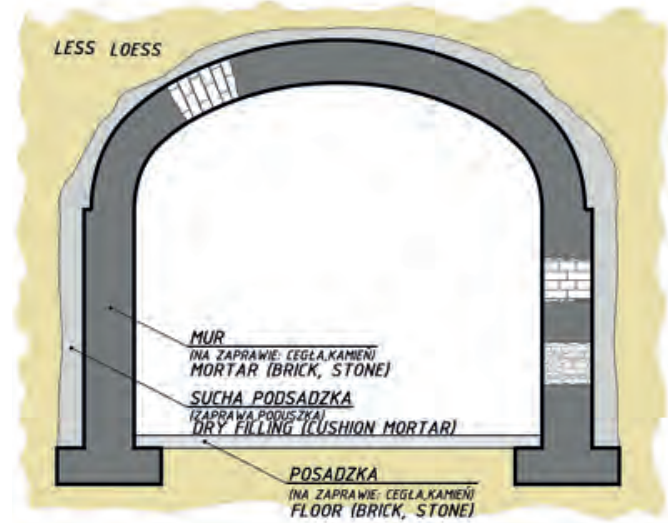

Fig. 2. Geometry of stone/brick vaults applied to protect loess ledges while the reconstruction of underground communication systems in Sandomierz. Examples: a - Casimir the Great Hall; b - Leszek the Black Gallery; c - Basket Chamber

Rys. 2. Geometria murowanych sklepień zastosowanych do zabezpieczenia lessowych wyłomów w trakcie odbudowy podziemnych układów komunikacyjnych w Sandomierzu. Przykłady: a - Sala Kazimierza Wielkiego; b - Chodnik Leszka Czarnego; c - Komora Koszowa 
the task of which was providing the stability to underground voids and preserving their transverse profiles during their use. The specifics of existing excavations, their geometry and architecture, their layout, the need to make totally new fragments joining the caverns, made it necessary to apply mining methods during the implementation of the project, due to the transverse profile in the shape of the vault (ceiling).

The shape of the vaults was selected, inter alia, adequate to the magnitude of the predicted burdens, accepting the forms as: circular, elliptic or parabolic (fig. 2). In case of small burdens, the geometry of vaults takes a mild shape (slightly convex). With the increase of this burden and with simultaneous impact of the side burden, the shape of the lining is adjusted to the natural shape of the vault (Chudek 1968). When the cellars were shallow, closed linings were not required. Shallow cellars required deep and broad fundaments in the form of footings, as in figure 2, adjusted to the intensity of the burden, but - first of all - to geological conditions (compactness of bottom rocks, i.e. loess) and hydrological conditions.

In case of excavations in loess, lining the voids with bricks or crushed rocks, apart from reconstruction, architectonic and aesthetic value, the lining had yet another role. It was the protection and securing the uncovered loess surface from atmospheric factors, especially humidity that would compromise the initial resistance of the rock.

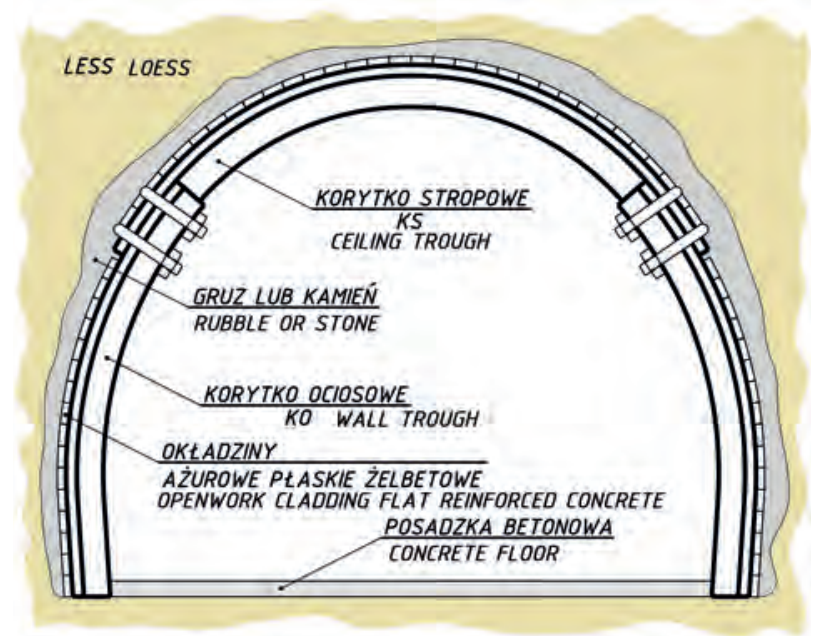

Fig. 3. Geometry of metal lining applied to protect loess ledges in the Mine Chamber in Sandomierz

Rys. 3. Geometria metalowej obudowy zastosowanej do zabezpieczenia lessowych wyłomów w Komorze Górniczej w Sandomierzu

\section{MORPHOMETRIC CHARACTERISTIC AND 3D VISUALIZATION OF THE UNDERGROUND TOURIST ROUTE}

The only full information preserved up till now is the cartographic documentation of the Sandomierz Old Town made in 1960s in the form of the situation map. The content of this document was made available by the Sandomierz Conservator Mr. Marek Juszczyk. These are elements of superstructure (buildings, walls, roads and pavements) and outlines of cellars, which were inventoried, protected and rebuilt for the needs of the owners of real estates and the Underground Tourist Route. The combination of the archive content with the present measurements of PTT in AutoCAD program, by putting archive data and present data (of the direct measurement PTT carried out by the author), allows us to define to what extent primary structure of the underground excavation was preserved, and to what extent it is the implementation of the concept by prof. Z. Strzelecki. To make the constructions more attractive and stress immense contribution of mining brigades in the project, the Mine Gallery (Chodnik Górniczy), architectonically different from the rest of the route was constructed (with steel lining $Ł P$, characteristic for coal mining fig. 3) and the Gwarek Shaft, with a spiral staircase (fig. 7) was also constructed. Both PTT elements in Sandomierz were transferred, although in other proportions to the Underground Tourist Route in Opatów. In case of the Sandomierz constructions, their localization guaranteed the continuity of the underground route and allowed combining the excavation under the western side of the Main Square (Rynek) with a small fragment of the cellars of the historic City Hall (fig. 5), making the route more attractive.

Figure 5 presents an image of the archive situation map of the Old Town (Staromiejska Dzielnica) of Sandomierz in a new vector form (vectorization and image: R. Gawałkiewicz), initially made by classical drawing methods.

The tourist object is located under the strict centre of the Old Town, under the western and north-western frontage of the Sandomierz Main Square. It is under the surface of the square in its north-western side, and the fragments are under the streets: Opatowska, Oleśnickich and Bartolona. Generalizing, the underground route is localized in the area of 0.63 ha and closed in a rect- 
angular of the following side lengths: $103.6 \mathrm{~m}$ (longitudinal) and $60.8 \mathrm{~m}$ (latitudinal). Mutual localization of underground cellars, as well as their situation towards the outline of the fundaments of houses often look random. This can be a result of the fact that they were built quite haphazardly, without using geometric services, and due to the change in the situation of the subsequent elements of the superstructure over the centuries. Very changeable history of the city, often suffering from fires, wars, which turned the city into ruins, could affect the state and layout of underground elements of the tourist route towards the present urbanistic layout. One can assume that the localization of the constructions (lines of superstructure and its character), with subsequent

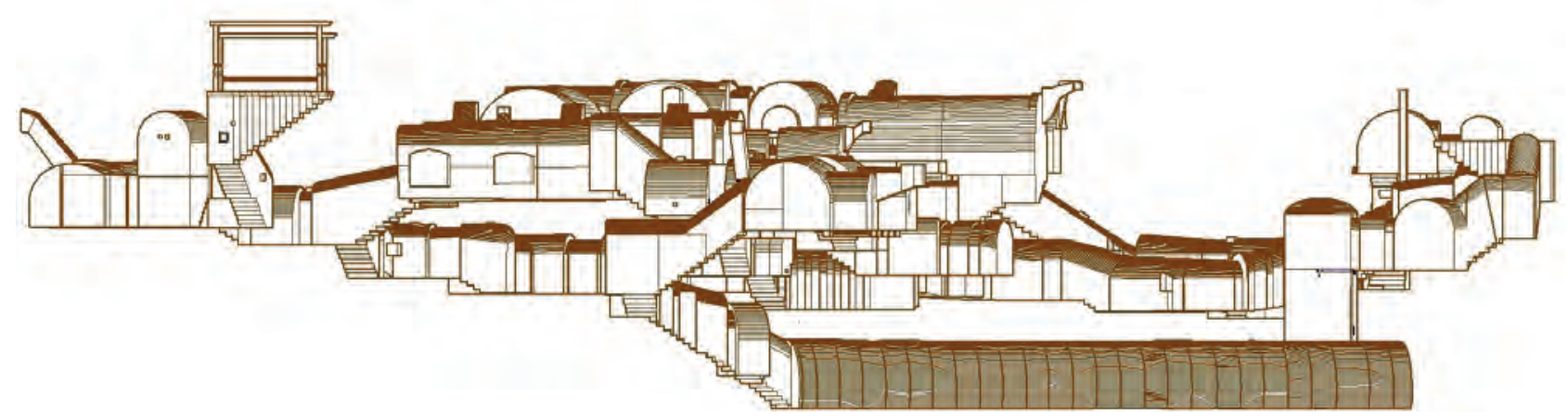

Fig. 4. Vertical projection of the Tourist Underground Route (from the southern side)

Rys. 4. Rzut pionowy Podziemnej Trasy Turystycznej w Sandomierzu (od strony południowej)

Table 1. The basic morphometric parameters of the Underground Tourist Trail (PTT) in Sandomierz (Gawałkiewicz R., 2018) Tabela 1. Podstawowe parametry morfometryczne Podziemnej Trasy Turystycznej (PTT) w Sandomierzu (Gawałkiewicz R., 2018)

\begin{tabular}{|c|c|}
\hline Parameters & Value \\
\hline $\begin{array}{l}\text { Trail length (calculated alongside the axis of corridors and cellars) } \\
\text { According to https://klubpodroznikow.com/relacje/polska/podziemia/1723-podziemna-trasa-turystycz- } \\
\text { na-w-sandomierzu }\end{array}$ & $\begin{array}{l}406.5 \mathrm{~m} \\
\sim 450 \mathrm{~m}\end{array}$ \\
\hline $\begin{array}{l}\text { According to https://sandomierz.eu/324/podziemna-trasa-turystyczna.html } \\
\text { Information board at the checkouts }\end{array}$ & $\begin{array}{l}\sim 470 \mathrm{~m} \\
\sim 500 \mathrm{~m}\end{array}$ \\
\hline Total area of the Underground Tourist Trail & $843.3 \mathrm{~m}^{2}$ \\
\hline $\begin{array}{l}\text { The area of PTT under squares and streets } \\
\text { Percentage of the total area of PTT }\end{array}$ & $\begin{array}{c}312.8 \mathbf{~ m}^{2} \\
37.1 \%\end{array}$ \\
\hline $\begin{array}{l}\text { The area of the biggest segment Mining Gallery } \\
\text { Percentage of the total area of PTT }\end{array}$ & $\begin{array}{c}71.9 \mathbf{~ m}^{2} \\
8.5 \%\end{array}$ \\
\hline Volume of voids $35 * \frac{\text { TYP } 4068}{61 m^{3}}$ & $2144 \mathrm{~m}^{3}$ \\
\hline Minimal ordinate of the floor - Mining Gallery & $179.63 \mathrm{~m}$ a.s.1 \\
\hline Maximal ordinate of the floor - first step of the stairs to PTT (courtyard) & $192.02 \mathrm{~m}$ a.s.1 \\
\hline Maximal depth of PTT (defined according to the ordinate of the courtyard) & $12.39 \mathrm{~m}$ a.s. 1 \\
\hline The number of stairs on the tourist trail & 347 \\
\hline Total number of stairs in the underground & 375 \\
\hline Number of rooms with proper names (according to Fig. 5) & 34 \\
\hline Number of all rooms included in the PTT complex & 58 \\
\hline
\end{tabular}




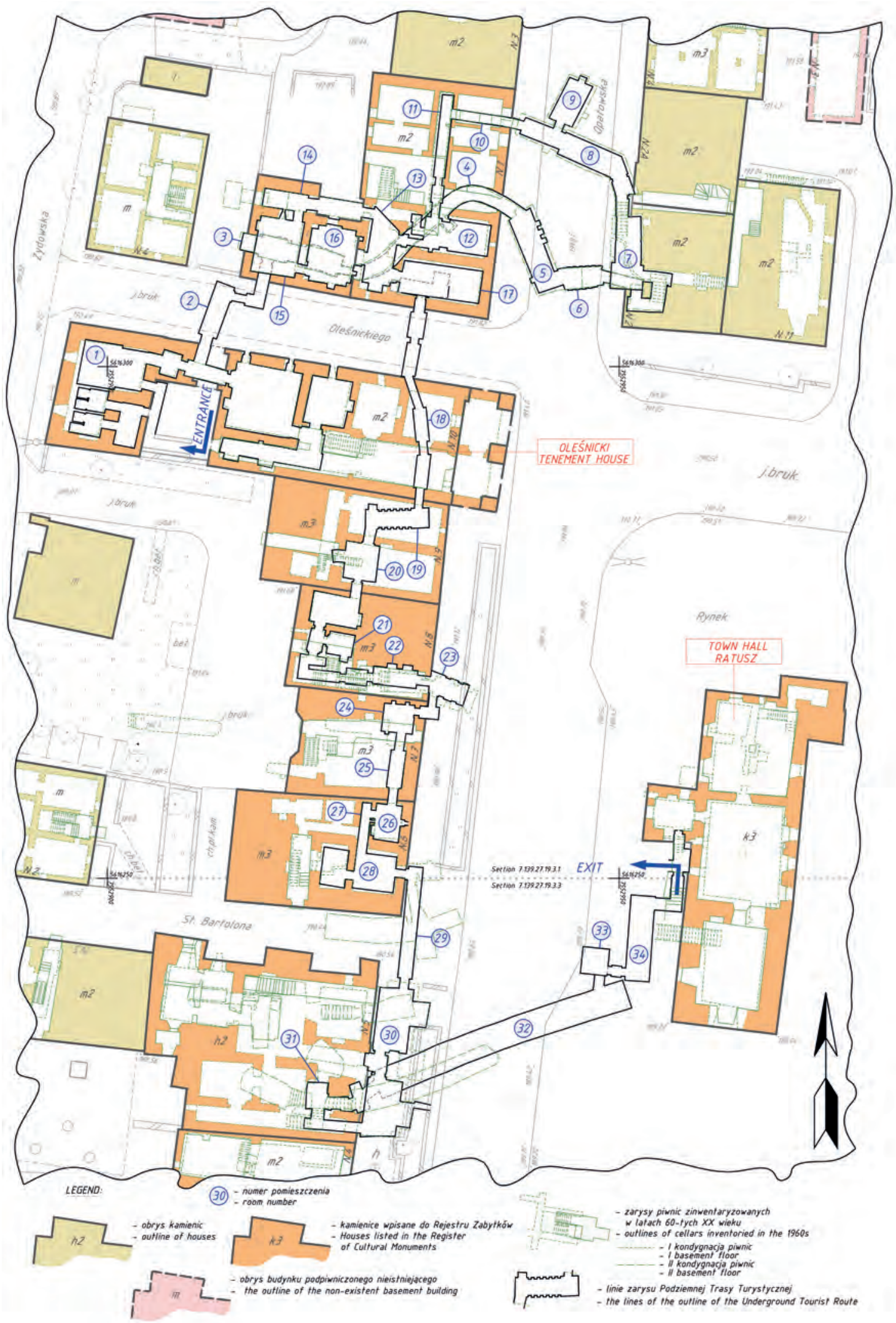




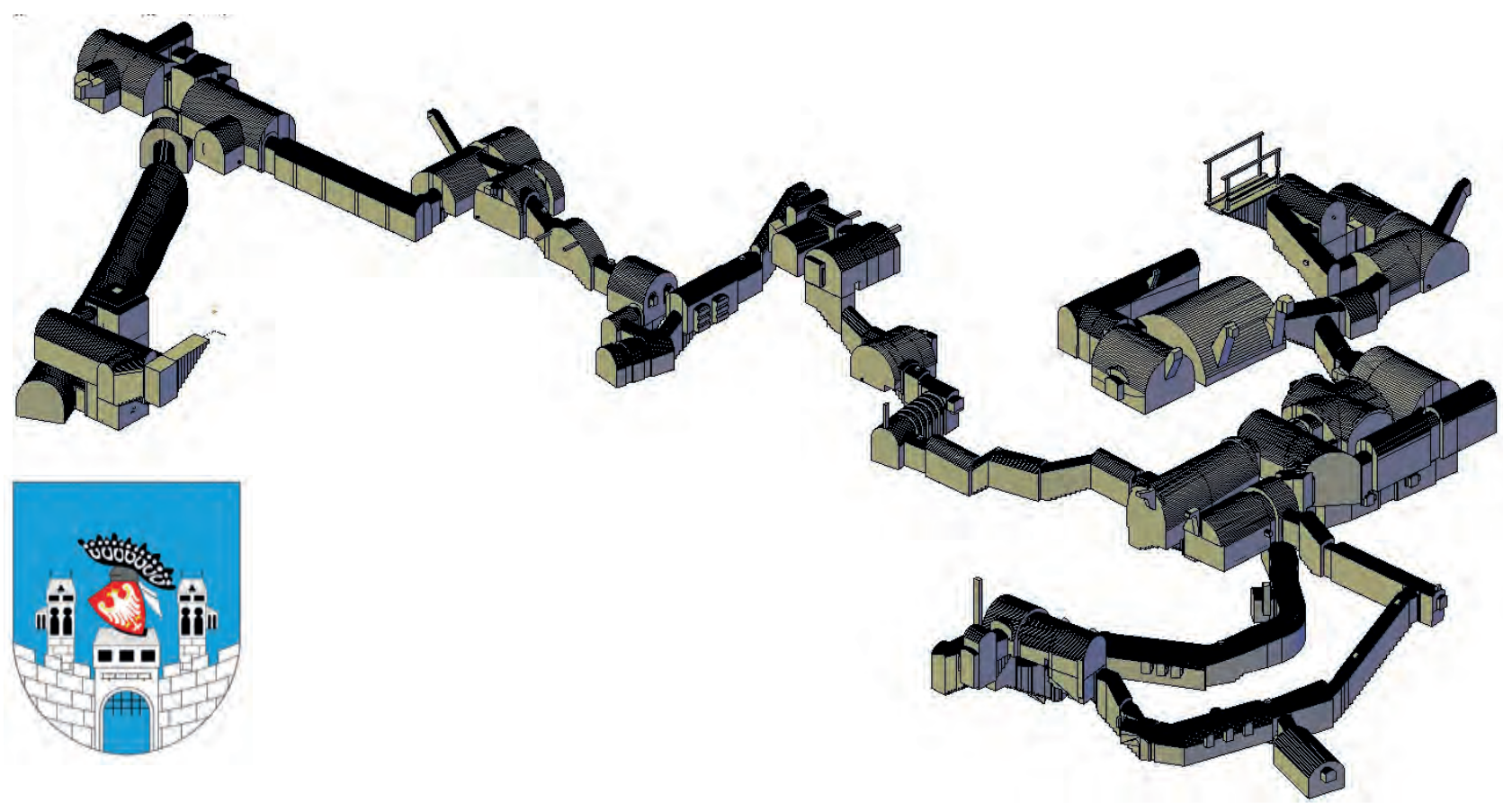

Fig. 6. The view of the Underground Tourist Route in Sandomierz - vistas from the north-east part

Rys. 6. Widok Podziemnej Trasy Turystycznej w Sandomierzu - widok perspektywiczny od strony północno-wschodniej

revitalizations of the city, changed significantly. Thus, there is a high geometric differentiation of the $2 \mathrm{D}$ underground route.

Considering the characteristic of the distribution of subsequent chambers on the route in the vertical plane, one can observe a complicated spatial system. The architectonic and construction documentation shows that the route is crossed by the systems of excavation located on various depths - fig. 6 . Figure 4 makes a valuable supplementation of $2 \mathrm{D}$ visualization (fig. 5). The visualizations allow to illustrate altitudinal and geometric diversity of subsequent fragments of the object and larger elements (chambers, halls, cellars, caverns, galleries, etc.). An important supplementation of the visualization in vertical (fig. 4) and horizontal (fig. 5) projections is the 3D model (fig. 6) made in AutoCAD, providing the full image of the "Sandomierz Dungeons".

The added value of the model is spatial visualization of various and unique details such as: lattice doors and iron-fitted doors, window bars, stylized lamps, etc., making unusual interesting decoration of the Sandomierz underground. According to the author, every construction being a tourist attraction (especially a historic object), should contain the catalogue of the details of this type, also in the form of spatial models, which allows their reconstruction in case of destruction or damage of individual elements inflicted during the use of the object.

Fig. 5. Localization of PTT and the outlines of excavations inventoried during securing works in 1960s, against the outline of the superstructure

Rys. 5. Lokalizacja PTT oraz zarysów wyrobisk zinwentaryzowanych podczas prac zabezpieczających w latach 60 . XX w. na tle zarysu infrastruktury powierzchniowej

1. Komnata Haliny Krępianki, 2. Sala Oleśnickich, 3. Komora Koszowa, 4. Chodnik Leszka Czarnego, 5. Sala Kazimierza Wielkiego, 6. Komora Gotycka, 7. Komnata pod Frontonem, 8. Chodnik Straceńców, 9. Sala Katowska, 10. Kamienne Schodki, 11. Ciasny Targ, 12. Sala Kolebkowa, 13. Sala Tatarska, 14. Chodnik Kuszników, 15. Komora Znalezisk, 16. Komnata z Portalem, 17, Sala Narożna, 18. Chodnik Upadowy, 19. Komora Łukowa, 20. Komnata Rycerska, 21. Jarmarczna Buda, 22. Korytarz z Wnękami, 23. Ślepy Zaułek, 24. Sala Bobolów, 25. Korytarz Bakałarzy, 26. Sala Kmieca, 27. Korytarz Żakowski, 28. Komora Flisów, 29. Chodnik Rękodzielników, 30. Komory Kupieckie, 31. Sala pod Bursą, 32. Chodnik Górniczy, 33. Szyb Gwarków, 34. Sala Rady Miejskiej 


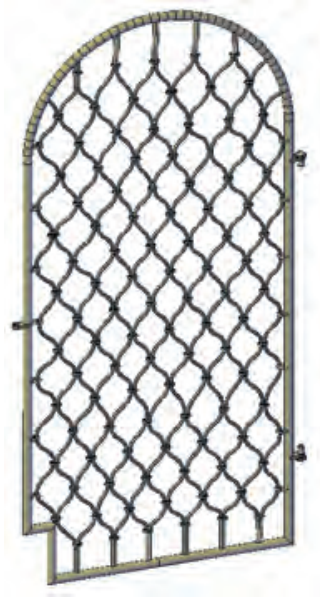

Drzwi kratowe - zejście do podziemi

Lattice doors - descent to the underground

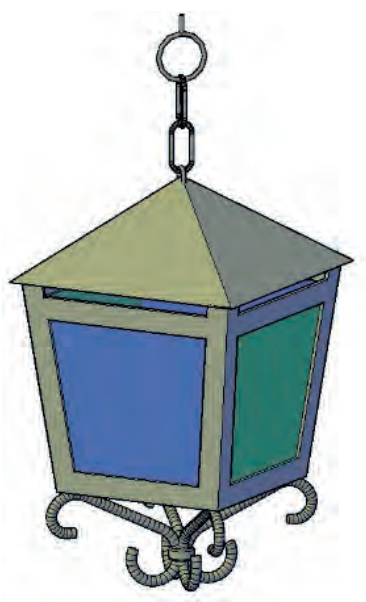

Lampa w Sali Oleśnickich Lamp in the Oleśnicki Hall

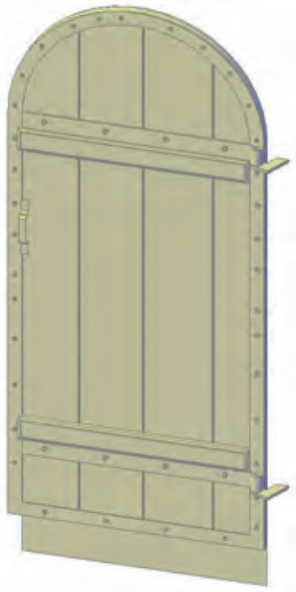

Drzwi do Komnaty Haliny Krępianki Door to Halina Krępianka's Chamber

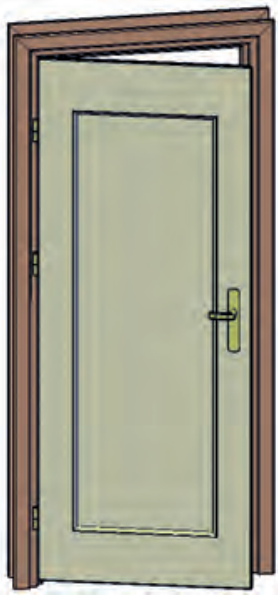

Drzwi do toalet Toilet doors

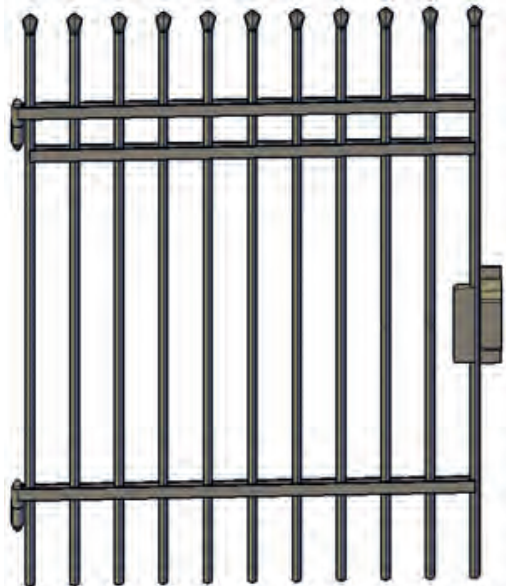

Krata - wejście do Sali Oleśnickich Lattice - entrance to the Oleśnicki Hall

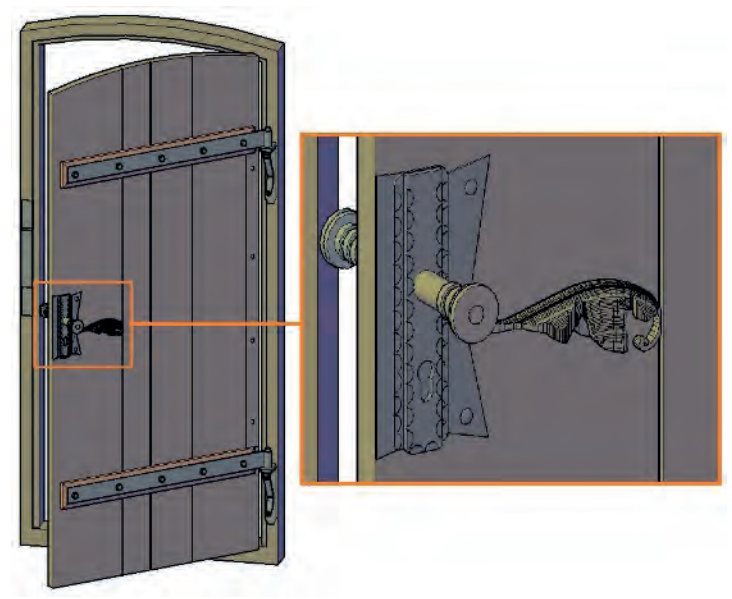

Drzwi do sali multimedialnej Doors to the multimedia room

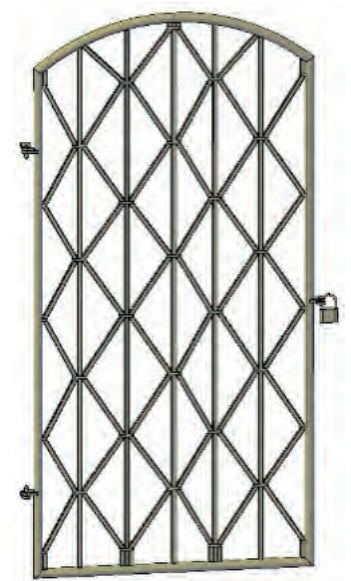

Drzwi kratowe - wejście do Sali Katowskiej Lattice doors - entrance to Executioner's Hall
Spatial modelling is not only the tool to make very distinct images, easy to interpret for tourists visiting the local attraction. This is also the set of interesting and precise micrometric data, which often seem interesting for people visiting these places. They make valuable supplementation of the history of this place, told by the local guides. Table 1 shows selected morphometric parameters of PTT in Sandomierz.

The total area of the voids in the Underground Tourist Route in Sandomierz is $843.3 \mathrm{~m}^{2}$, which approximately corresponds the area of 5 full-size volleyball courts. The parameterization of the object, based on the 3D model, allowed the corrections of the value of the total length of the route. In many advertising materials and websites (including the City Hall of Sandomierz), the length of the route is really overestimated and given as $\sim 450-\sim 500 \mathrm{~m}$.

\section{CONCLUSIONS}

Historic objects localized on the surface make basic attribute of the city attractiveness, and a unique added value is the Underground Tourist Route. The available 


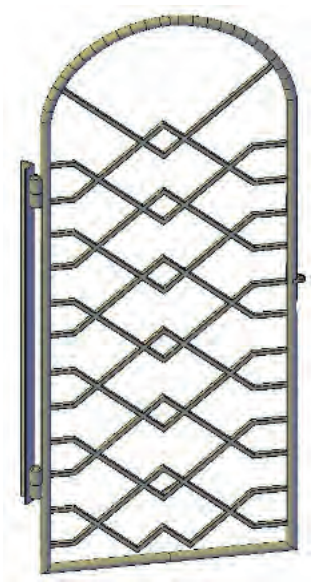

Drzwi kratowe - wejście do Sali Kolebkowej

Lattice doors - entrance to Barrel Hall

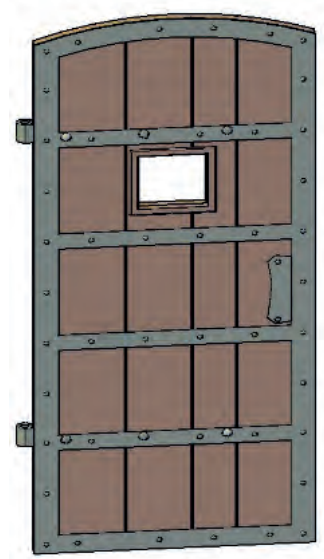

Drzwi do Jarmarcznej Budy Doors to The Fairhouse

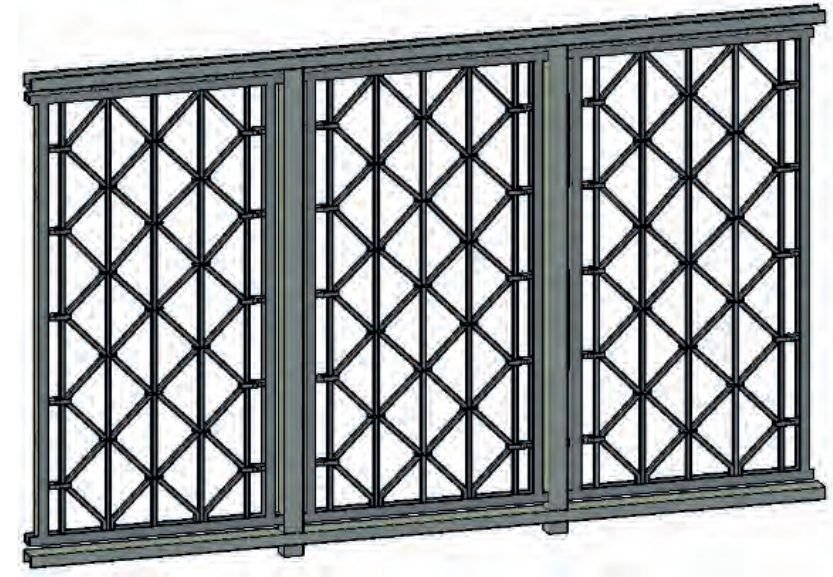

Krata rozdzielająca w Sali Tatarskiej

Separating lattice in the Tatar Hall

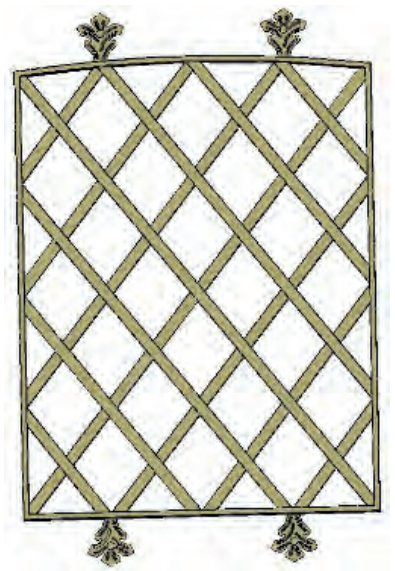

Krata okienna w Komorze Flisów Window grille in the Flis Chamber

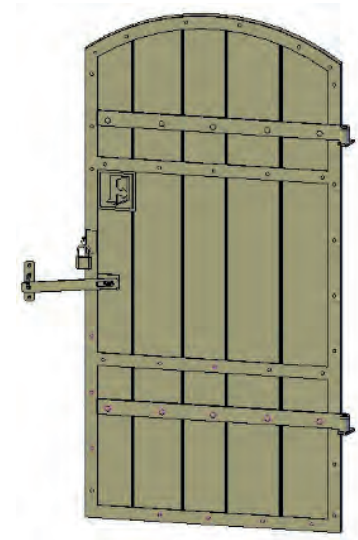

Drzwi boczne Komory Flisów Side doors of the Flis Chamber

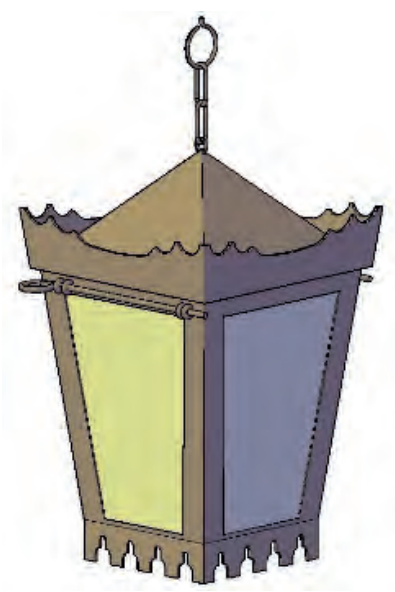

Lampy w Chodniku Kuszników Lamps in the Crossbowmen's Walkway

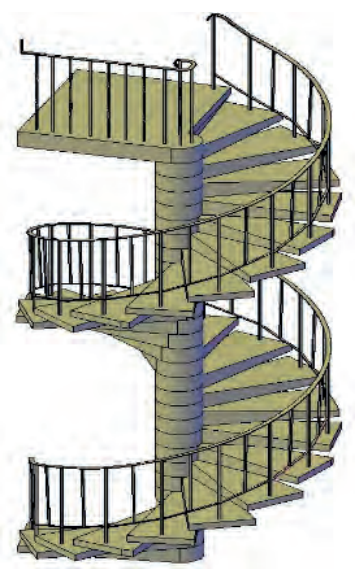

Schody w Szybie Gwarków Stairs in Gwarkow Shafts

Fig. 7. The most interesting examples of the inventoried details of PTT in Sandomierz and their localization Rys. 7. Najciekawsze przykłady zinwentaryzowanych detali PTT w Sandomierzu i ich lokalizacja

measurement technologies make possibility of the inventory of even most geometrically complicated engineering constructions. Nowadays, the combination of data from surveying technologies and information (graphical) technologies allows very detail visualizations in the area of engineering documentation (projections, profiles, visualization) of various types of objects of natural and anthropogenic origin. This is also the way of their precise parameterization.

The presented 3D visualization gives a real image of the spatial system of the object, which is difficult to imagine during visiting the underground. The marked morphometric parameters of the constructions make precious source of information for the guides of Sandomierz, but it is also information, which makes tourists aware of the scale (size) of constructions and information to renovation teams in making such an geometrically object. Presented in article graphical information (3D visualization of the route and details, $2 \mathrm{D}$ visualisation - horizontal and vertical projections), in combination with morphometric data and history of the object, can make the content of a valuable card of scientific 
documentation, which should be made for this type of constructions for the conservation needs, as well as for the users, custodians or tenants.

\section{REFERENCES}

Chudek Mirosław. 1968. Obudowa wyrobisk. Obudowa kamienna, metalowa i mieszana, Górnictwo t. VII, cz. 2, Wydawnictwo „Śląsk”, Katowice.

Gawałkiewicz Rafał, Szafarczyk Anna. 2017. Analysis of height changes in the old historical Quarter of Sandomierz in the aspect of the protection of buildings and underground infrastructure. $17^{\text {th }}$ International Multidisciplinary Scientific GeoConference SGEM 2017, Albena, Bulgaria: 83-90.

Gawałkiewicz Rafał. 2018. The application of laser scanning technology in documenting historical underground object in Sandomierz (Poland). $18^{\text {th }}$ International Multidisciplinary Scientific GeoConference SGEM 2018, Albena, Bulgaria: 1003-1010.
Glinicki Stanisław Paweł. 1994. Budowle podziemne. Wydawnictwa Politechniki Białostockiej, Białystok.

Krawczyk Jan. 2010. Ocena aktualności studium uwarunkowań i kierunków zagospodarowania przestrzennego oraz aktualności miejscowych planów zagospodarowania przestrzennego miasta Sandomierza wraz z analiza zmian $w$ zagospodarowaniu przestrzennym miasta Sandomierza. Sandomierz

Mikoś Tadeusz, Chmura Janusz, and Tajduś Antoni. 2013. Górnicze metody ratowania zabytkowych dzielnic staromiejskich [in:] 75 lat doświadczeń Akademii Górniczo-Hutniczej im. Stanistawa Staszica w Krakowie. Wydawnictwa Naukowo-Dydaktyczne AGH. Kraków.

Ochirsukh Khulgun. 2019. An example of using CAD software in themodeling of mining excavations of the historical salt mine Bochnia. Geoinformatica Polonica vol 18: 135-144. DOI 10 .4467/21995923GP.19.011.11578.

Tajduś Antoni, Mikoś Tadeusz, and Chmura Janusz. 2008. Doświadczenia AGH w badaniu i zabezpieczaniu podziemi Krakowa. AGH Uczelniane Wydawnictwa Naukowo-Dydaktyczne. Kraków: 77-84. 